\title{
Effect of Dietary Vitamin C Supplementation on the Blood Parameters of Striped Bass Morone saxatilis (Walbaum, 1752)
}

\author{
Francesco Fazio ${ }^{1, *}$ (D) Carmelo laria², Concetta Saoca ${ }^{1}$, Antonio Costa $^{3}$, Giuseppe \\ Piccione $^{1}$, Nunziacarla Spanò ${ }^{4}$
}

${ }^{1}$ University of Messina, Department of Veterinary Sciences, Polo Universitario dell'Annunziata, 98168, Messina, Italy. 2Department of Chemical, Biological, Pharmaceutical and Environmental Sciences, via F. Stagno d'Alcontres 31, University of Messina, 98165 Messina, Italy.

${ }^{3}$ Porrazzito S.r.I. Acate (RG).

${ }^{4}$ Department of Biomedical, Dental Sciences and Morphological and Functional Images, University of Messina, Italy.

\section{Article History}

Received 02 August 2019

Accepted 10 December 2019

First Online 16 December 2019

\section{Corresponding Author}

Tel.: +390906766516

E-mail: ffazio@unime.it

\section{Keywords}

Ascorbic Acid

Cultured Fish

Biochemical Parameters

Haematological Values

Growth Performance

\begin{abstract}
The aim of this study was to evaluate the effect of dietary vitamin C supplementation on the blood and biometric parameters of striped bass Morone saxatilis (Walbaum, 1752). For the trial, two groups fed for sixty days were used: group A (basic feed with low vitamin C concentration) and group B (high vitamin C supplement feed). Twenty fish from each group were selected and blood samples were collected to analyse the following blood parameters: white blood cell (WBC), red blood cell (RBC), haemoglobin concentration $(\mathrm{Hb})$, haematocrit $(\mathrm{Hct})$, mean corpuscular volume $(\mathrm{MCV})$, mean corpuscular haemoglobin $(\mathrm{MCH})$, mean corpuscular haemoglobin concentration (MCHC), thrombocytes (TC), albumin (ALB), total bilirubin (TBIL), aspartate aminotransferase (AST); alanine aminotransferase (ALT), alkaline phosphatase (ALP), creatine kinase (CK), gamma-glutamyl transferase (GGT), lactate dehydrogenase $(\mathrm{LDH})$, chlorine $(\mathrm{Cl})$, potassium $(\mathrm{K})$, sodium $(\mathrm{Na})$, calcium $(\mathrm{Ca})$, magnesium $(\mathrm{Mg})$, phosphorus (P), creatinine (CREA) and urea. For all fish, weight, total length and condition factor $(K)$ were registered. Unpaired t-test showed significant differences in biometric indices and some blood parameters between the two groups. Vitamin $C$ supplement improves fish growth and influences important blood parameters that indicate the health status of fish. These results are useful for food management in aquaculture systems of striped bass.
\end{abstract}

\section{Introduction}

Today, fish nutrition and its effect to animal health is an important new field of study in the aquaculture industry (Lo Cascio et al., 2018; Marino et al., 2016).

Fish diseases, feed contamination, water parameters and mortality rates are some of the problems that need to be addressed in intensive aquaculture; for this reason, it is necessary to formulate suitable artificial diets to properly satisfy the dietary requirements of farmed fish (Kopp, Mareš, Lang, Brabec, \& Ziková, 2014; Wilson, Halver, \& Hardy, 2002).

Fish haematology can reveal important information on fish physiology and health and represents an important tool of aquaculture (Fazio, 2018; Percin \& Konyalioglu, 2008; Percin, Konyalioglu, Firat, \& Saka, 2010).

Nutritional needs of animals depend on various factors such as species, living habitat and growth stage (Sargent, Henderson, \& Tocher, 1989). Among all the essential elements, vitamins (including vitamin C) are important for every animal species including aquatic organisms (Percin et al., 2010; Sogut \& Percin, 2011).

Vitamin C (ascorbic acid) is an essential nutrient for metabolic and physiological functions (normal growth, immunity system, reproduction) (Okhionkpamwonyi \& Edema, 2017). It also plays an antioxidant action protecting cells against free radicals (Chen et al., 2004; 
Kiron, Puangkaew, Ishizaka, Satoh, \& Watanabe, 2004; Sahoo \& Mukherjee, 2002; Sau, Paul, Mohanta, \& Mohanty, 2004) and facilitates inflammatory response (Petric et al., 2018; Renò, Aina, Gatti, \& Cannas, 2005).

Despite the fact that biosynthesis of vitamin C occurrs in several animals, most fish species are unable to synthesize it (Chatterjee, 1973) as they do not have the enzyme L-gulonolattone oxidase which is responsible for synthesis from glucose (Darias, Mazurais, Koumoundouros, Cahu, \& ZamboninoInfante, 2011); therefore, vitamin $C$ must be supplied with the diet (Dabrowski, 2000).

Previous research showed the positive effect of dietary vitamin supplementation on fish physiological stress, improving the performance of cultured fish and decreasing mortality (De Andrade et al., 2007; Montero, Tort, Robaina, Vergara, \& Izquierdo, 2001; Shiau \& Hsu, 2002).

It was also widely demonstrated that supplementation of fish feed with high vitamin $\mathrm{C}$ doses stimulates the immune system enhancing antibody production, improving the immune response and preventing diseases (Azad, Dayal, Poornima, \& Ali, 2007; Ortuño, Esteban, \& Meseguer, 2003; Puangkaew et al., 2004).

Deficiencies of vitamin C in fish produce several morphological and physiological dysfunctions and abnormalities with clear clinical manifestations; this has been reported by several authors in previous works on various fish species (Alexis, Karanikolas, \& Richards, 1997; Bahram Falahatkar, Dabrowski, \& Arslan, 2011; Lewis-McCrea \& Lall, 2010; Sealey \& Gatlin III, 2002; Wilson et al., 2002; Zhou, Wang, Wang, Xie, \& Wang, 2012). Skeletal alterations, reduced growth, internal bleeding and increased mortality are some of the most important dysfunctions that can occur in fish deprived of vitamin C.

Our study investigated the effects of commercial feeds supplemented with different concentrations of vitamin C (ascorbic acid) on the biometric, haematological and some haematochemical parameters in striped bass Morone saxatilis (Walbaum, 1752) to establish the beneficial effect of vitamin $C$ on growth and blood parameters of this species.

\section{Materials and Methods}

\section{Experimental Design}

This study was performed on 40 adult striped bass M. saxatilis. General condition and health status of fish were evaluated by an external examination for any signs of abnormalities or infestations (Gaglio et al., 2016; Iaria et al., 2018; laria, et al., 2019); on the basis of this, all fish were considered healthy (laria, et al., 2019). Fish, coming from a Sicilian farm, in southern Italy, were bred in a recirculating aquaculture system (RAS) containing 6 tanks $\left(8 \mathrm{~m}\right.$ in diameter and $60 \mathrm{~m}^{3}$ in volume; stock density of $20 \mathrm{Kg}^{-3}$ ). Water filtration was carried out with drum and biological filters and an anti-bacterial UV system (200-280 nm). Fish were bred under conditions of seasonal temperature and constant water parameters (Table 1) and fed twice a day. Before the trial, all fish showed mean body weight of 350-355 g. For the trial, we used two groups, in triplicate at the same conditions, fed for sixty days: group A (control with basic feed) using VERONESI BASIC 6G (protein 42\%, lipid 18\%, fiber $3.2 \%$, ash $9 \%$, phosphorus $1.4 \%$, vitamin C 150 $\mathrm{mg} / \mathrm{kg}$, vitamin E $150 \mathrm{mg} / \mathrm{kg}$ )) and group B (supplement Vitamin ( feed) using BIOMAR EFICO KAPPA $856 \mathrm{~W}$ (protein $42 \%$, lipid $16 \%$, fiber $3.5 \%$, ash $6.2 \%$, phosphorus $1.4 \%$, vitamin C $500 \mathrm{mg} / \mathrm{kg}$, vitamin E 150 $\mathrm{mg} / \mathrm{kg}$ ). Each group was reared in triplicate in three different tanks at the same experimental conditions.

After the experimental period we analysed 20 fish from each group, which were sampled randomly from the two groups of three different tanks. Prior to blood sampling, fish were anesthetized using biphenoxyethanol at a concentration of $0.6 \mathrm{mg} / \mathrm{L}$ (Carmelo laria, Saoca, et al., 2019). Immediately after anaesthetization, the fish were individually weighed using a precision balance (Kern 440-49 N, Germany) and total length was recorded using an ictiometer (Scubla $\mathrm{SNC}, 600 \mathrm{~mm}$, Italy). The Condition Factor (K) was also

Table 1. Range of water parameters in recirculating aquaculture system (RAS) for Striped bass M. saxatilis

\begin{tabular}{lcc}
\hline Parameters & Values & Ranges \\
\hline $\mathrm{T}$ & $23,5^{\circ} \mathrm{C}$ & $20<\mathrm{X}<27^{\circ} \mathrm{C}$ \\
$\mathrm{OD}$ & $5 \mathrm{mg} / \mathrm{L}$ & $4.5<\mathrm{X}<7.5 \mathrm{mg} / \mathrm{L}$ \\
$\mathrm{pH}$ & 7 & $6.8<\mathrm{X}<8.0$ \\
$\mathrm{NH}_{3}$ & $0.01 \mathrm{mg} / \mathrm{L}$ & $0.00<\mathrm{X}<0.2$ \\
$\mathrm{NO}_{2}$ & $0.2 \mathrm{mg} / \mathrm{L}$ & $0.00<\mathrm{X}<0.5 \mathrm{mg} / \mathrm{L}$ \\
$\mathrm{NO}_{3}$ & $100 \mathrm{mg} / \mathrm{L}$ & $0.00<\mathrm{X}<800 \mathrm{mg} / \mathrm{L}$ \\
$\mathrm{CTD}$ & $1000 \mu \mathrm{S} / \mathrm{cm}$ & $400<\mathrm{X}<2000 \mu \mathrm{S} / \mathrm{cm}$ \\
\hline
\end{tabular}

Note: T (Temperature); OD (Dissolved Oxygen); $\mathrm{pH} ; \mathrm{NH}_{3}$ (Ammonia); $\mathrm{NO}_{2}$ (Nitrite); $\mathrm{NO}_{3}$ (Nitrate); CTD (Conductivity). 
calculated as $W \times 100 / L^{3}$ where $W$ is the weight of the fish in grams $(\mathrm{g})$, and $\mathrm{L}$ is the length of the fish in centimetres $(\mathrm{cm})$. Blood samples were collected from individual fish on the same day, at 9 a.m., fasting, and were obtained from the caudal vein using sterile plastic syringe $(2.5 \mathrm{~mL})$. The samples were transferred into two different aliquots: one into microtubes containing ethylenediamine tetraacetic acid (EDTA) (ratio 1.26 $\mathrm{mg} / 06 \mathrm{~mL}$ ) (Miniplast $0.6 \mathrm{~mL}$; LP Italiana Spa, Milano) as anticoagulant agent for the assessment of haematological profile, and one into a tube without anticoagulant for serum sample necessary to assess haematochemical parameters. Five fish were randomly sampled for histopathological analysis.

\section{Automatic Haematological Analysis}

Assessment of haematological parameters (white blood cell, WBC; red blood cell, RBC; haemoglobin concentration, $\mathrm{Hb}$; haematocrit, $\mathrm{Hct}$; mean corpuscular volume, $\mathrm{MCV}$; mean corpuscular haemoglobin, $\mathrm{MCH}$; mean corpuscular haemoglobin concentration, $\mathrm{MCHC}$ thrombocytes, TC) was performed immediately after blood collection by an automatic method using a blood cell counter, HeCo Vet C (SEAC, Florence, Italy). This instrument uses a special lysing reagent for fish (SEAC, Code 71010460) previously employed to investigate haematological profile in various fish species (Fazio et al., 2013; Fazio, Saoca, Casella, Fortino, \& Piccione, 2015; Fazio et al., 2019; Fazio, Saoca, Vazzana, \& Piccione, 2017; Fazio, Arfuso, Levanti, Saoca, \& Piccione, 2017; Fazio et al., 2013). Furthermore, this technique has been validated by Fazio et al., (2012) . All blood samples were analysed in triplicate by the same operator. To validate the reliability of the automatic method, a manual haematological analysis was also performed on all samples.

\section{Haematochemical Parameters}

For haematochemical analysis, sera were obtained by centrifugation $\left(10 \mathrm{~min}\right.$ at $3000 \mathrm{rpm}$ at $4{ }^{\circ} \mathrm{C}$ ) of blood samples and stored at $-20{ }^{\circ} \mathrm{C}$ until needed. Measured haematochemical parameters include: albumin (ALB), total bilirubin (TBIL), aspartate aminotransferase (AST); alanine aminotransferase (ALT), alkaline phosphatase $(A L P)$, creatine kinase $(C K)$, gamma-glutamyl transferase $(\mathrm{GGT})$, lactate dehydrogenase (LDH), chlorine (Cl), potassium (K), sodium ( $\mathrm{Na})$, calcium (Ca), magnesium $(\mathrm{Mg})$, phosphorus $(\mathrm{P})$, creatinine (CREA) and urea, which were determined by means of commercial kits (SEAC, Florence, Italy) using an automated analyser UV Spectrophotometer (SEAC, Slim, Florence, Italy). All blood samples were analysed in triplicate by the same operator.

Protocols of animal husbandry and experimentation were reviewed and approved in accordance with the standards recommended by the
Guide for the Care and Use of Laboratory Animals and Directive 2010/63/EU for animal experiments.

\section{Statistical Analysis}

Analytical data, represented as mean \pm standard deviation (SD), are the averages of three analyses carried out by the same operator.

Prior to statistical analysis, all obtained data were tested for normality using the Kolmogorov-Smirnov test. An unpaired $t$-test was applied to evaluate existing statistically significant differences in the haematological and haematochemical parameters between group $A$ and group B of $M$. saxatilis. $P$ values $<0.05$ were considered statistically significant.

All results are expressed as mean \pm standard deviation (SD). Data were analysed using statistical software prism v. 5.00 (Graphpad Software Ltd., USA, 2003).

\section{Results}

After 60 days of feeding trial, the basic feed (VERONESI BASIC 6G) showed a feed conversion ratio (FCR) of 1.3 and the higher Vitamin $C$ supplement feed (BIOMAR EFICO KAPPA $856 \mathrm{~W}$ ) showed a 1.25 FCR.

Mean values \pm SD of the haematological and haematochemical parameters evaluated in striped bass M. saxatilis (Walbaum, 1792) are reported in Table 2 and 3 respectively.

Unpaired $t$-test showed statistically significant differences in the biometric indices as weight and total length, in some blood parameters, WBC, RBC and $\mathrm{MCH}$ (Table 2) and ALT, LDH and P between the two groups of fish (Table 3). No statistical differences were found for the other studied blood parameters ( $\mathrm{Hb}, \mathrm{Hct}, \mathrm{MCV}$, MCHC, TC, ALB, TBIL, AST, ALP, CK, GGT, Cl, K, Na, Ca, $\mathrm{Mg}, \mathrm{CREA}$ and urea).

Histopathological analysis did not show any sign of disease.

All data were analysed using statistical software Prism v.5.00 (Graphpad Software Ltd., USA, 2003).

\section{Discussion}

Our results show significant differences in biometric indices (weight and total length), and haematological (WBC, RBC and $\mathrm{MCH}$ ) and haematochemical parameters ( $A L T, L D H$ and $P$ ) between the two groups of $M$. saxatilis fed with two different diets.

In this study, the fish fed with a diet strongly supplemented with vitamin C (group B) showed weight and total length values which were significantly higher compared to fish fed with a diet with a low vitamin supplementation (group A). These data indicate that dietary vitamin C improves the growth performance of M. saxatilis in accordance with previous works on other 
Table 2. Mean values \pm SD of biometric indices and hematological parameters of striped bass Morone saxatilis (Walbaum, 1792) in group A (control) and group B (Vit C supplemented) after 60-day feeding trial. Means without the same alphabetical characters within the same parameters represent statistical differences $(P<0.05)$

\begin{tabular}{|c|c|c|}
\hline \multirow{2}{*}{ Parameters } & \multicolumn{2}{|c|}{ Means $\pm S D$} \\
\hline & Group A & Group B \\
\hline Weigh (g) & $448.50 \pm 25.07^{a}$ & $518.00 \pm 21.03^{b}$ \\
\hline Total length (cm) & $35.25 \pm 0.64^{\mathrm{a}}$ & $37.95 \pm 0.49^{b}$ \\
\hline Condition factor $\mathrm{K}$ & $1.01 \pm 0.03$ & $0.95 \pm 0.02$ \\
\hline WBC $\left(\times 10^{3} / \mu \mathrm{L}\right)$ & $30.94 \pm 2.07^{a}$ & $36.49 \pm 1.66^{b}$ \\
\hline $\mathrm{RBC}\left(\times 10^{6} / \mu \mathrm{L}\right)$ & $2.95 \pm 0.09^{a}$ & $3.25 \pm 0.06^{b}$ \\
\hline $\mathrm{Hb}(\mathrm{g} / \mathrm{dL})$ & $10.66 \pm 0.25$ & $11.04 \pm 0.18$ \\
\hline Hct (\%) & $34.62 \pm 1.11$ & $35.88 \pm 0.98$ \\
\hline $\mathrm{MCV}(\mathrm{fL})$ & $118.2 \pm 3.67$ & $110.80 \pm 3.89$ \\
\hline $\mathrm{MCH}(\mathrm{pg})$ & $36.34 \pm 0.76^{a}$ & $34.10 \pm 0.53^{b}$ \\
\hline $\mathrm{MCHC}(\%)$ & $31.14 \pm 0.86$ & $31.20 \pm 1.02$ \\
\hline $\mathrm{TC}\left(\times 10^{3} / \mu \mathrm{L}\right)$ & $87.30 \pm 1.30$ & $87.15 \pm 0.92$ \\
\hline
\end{tabular}

Note: SD (standard deviation); WBC (white blood cell); RBC (red blood cell); Hb (hemoglobin concentration); Hct (hematocrit); MCV (mean corpuscular volume); $\mathrm{MCH}$ (mean corpuscular hemoglobin); $\mathrm{MCHC}$ (mean corpuscular hemoglobin concentration); TC (thrombocytes).

Table 3. Mean values \pm SD of haematochemical parameters of striped bass Morone saxatilis (Walbaum, 1792) in group A (control) and group $B$ (Vit $C$ supplemented) after 60 -day feeding trial. Means without the same alphabetical characters within the same parameters represent statistical differences $(P<0.05)$

\begin{tabular}{|c|c|c|}
\hline \multirow{2}{*}{ Parameters } & \multicolumn{2}{|c|}{ Means \pm SD } \\
\hline & Group A & Group B \\
\hline ALB (g/L) & $13.80 \pm 0.20$ & $13.60 \pm 0.10$ \\
\hline TBIL ( $\mu \mathrm{mol} / \mathrm{L})$ & $13.85 \pm 1.00$ & $14.02 \pm 1.30$ \\
\hline AST (U/I) & $32.00 \pm 2.25$ & $26.40 \pm 1.70$ \\
\hline ALT (U/I) & $0.55 \pm 0.11^{a}$ & $0.85 \pm 0.08^{b}$ \\
\hline $\operatorname{ALP}(U / I)$ & $62.40 \pm 1.65$ & $61.45 \pm 1.51$ \\
\hline CK (U/I) & $414.30 \pm 25.97$ & $443.50 \pm 33.98$ \\
\hline GGT (U/I) & $0.80 \pm 0.15$ & $0.90 \pm 0.14$ \\
\hline LDH (U/I) & $112.10 \pm 4.53^{a}$ & $95.85 \pm 4.98^{b}$ \\
\hline $\mathrm{Cl}(\mathrm{mmol} / \mathrm{L})$ & $145.30 \pm 0.57$ & $143.80 \pm 0.54$ \\
\hline $\mathrm{K}(\mathrm{mmol} / \mathrm{L})$ & $5.49 \pm 0.22$ & $5.10 \pm 0.24$ \\
\hline $\mathrm{Na}(\mathrm{mmol} / \mathrm{L})$ & $164.20 \pm 0.69$ & $162.60 \pm 0.69$ \\
\hline $\mathrm{Ca}(\mathrm{mmol} / \mathrm{L})$ & $3.41 \pm 0.07$ & $3.35 \pm 0.06$ \\
\hline $\mathrm{Mg}(\mathrm{mmol} / \mathrm{L})$ & $1.16 \pm 0.03$ & $1.18 \pm 0.03$ \\
\hline $\mathrm{P}(\mathrm{mmol} / \mathrm{L})$ & $3.03 \pm 0.06^{a}$ & $2.72 \pm 0.08^{b}$ \\
\hline CREA $(\mu \mathrm{mol} / \mathrm{L})$ & $15.91 \pm 1.50$ & $18.56 \pm 1.50$ \\
\hline UREA (mmol/L) & $0.010 \pm 0.00$ & $0.01 \pm 0.00$ \\
\hline
\end{tabular}

Note: ALB (albumin); TBIL (total bilirubin); aspartate aminotransferase (AST); alanine aminotransferase (ALT); alkaline phosphatase (ALP); creatine kinase (CK); gamma-glutamyl transferase (GGT); lactate dehydrogenase (LDH); chlorine (CI); potassium (K); sodium (Na); calcium (Ca); magnesium (Mg); phosphorus (P); creatinine (CREA).

species of fish such as Japanese seabass (Lateolabrax japonicas) (Ai et al., 2004), juvenile grouper (Epinephelus Malabaricus) (Lin \& Shiau, 2005) and rainbow trout Oncorhynchus mykiss (Dadar et al., 2016), in which a positive effect of Vitamin $C$ on growth was shown.

Regarding the effect of vitamin C on haematology and biochemistry of striped bass $M$. saxatilis, as well as biometric indices, also some of the blood parameters studied in our research (WBC, RBC and LDH) exhibited significant differences in the two groups. In particular, WBC and RBC showed significantly higher values $(P<$ 0.05 ) in group $B$ than group $A$. Similar results were previously found by Nsonga, Kang'Ombe, Mfitilodze, Soko, and Mtethiwa (2009) in juvenile tilapia (Oreochromis karongae) (Trewavas 1941). Falahatkar (2005), in his research on the effect of different levels of diet vitamin $C$ on haematological parameters of great sturgeon (Huso huso) (Linnaeus 1758), showed that there were significant differences in WBC in relation to different levels.

A significant influence of diets containing different levels of vitamin C on RBC values has also been observed in channel catfish (Ictalurus punctatus) (Refinesque 1818) (Lim, Klesius, Li, \& Robinson, 2000), in gilthead seabream (Sparus aurata) (Linnaeus 1758) (Montero et 
al., 2001) and in piracuru (Arapaima gigas) (Cuvier 1829) (De Andrade et al., 2007).

The significant influence of vitamin C on WBC and $R B C$ values is due to the powerful antioxidant action of vitamin $C$ that protects various tissues of fish, including WBC and RBC, against oxidative damage (Sahoo \& Mukherjee, 2003).

Farmed fish are frequently exposed to several stressors under culture conditions. WBC and RBC are useful indices of physiological response to stress in fish; leukocytes are involved in non-specific defence mechanisms of animals against situations of stress, inducing protection against diseases (Percin \& Sogut, 2010). Moreover, it is well known that the addition of vitamin $C$ in fish diet increases the production of antibodies against pathogens, thus reducing stress (Ai et al., 2004; Chen et al., 2004; Lin \& Shiau, 2005; Ortuño et al., 2003).

Unlike WBC and RBC, in our study, $\mathrm{MCH}$ values were significantly lower in group $B$.

$\mathrm{Hb}, \mathrm{Hct}, \mathrm{MCV}, \mathrm{MCHC}$ and TC showed no significant differences between groups $\mathrm{A}$ and $\mathrm{B}$.

Among all haematochemical parameters evaluated, only the enzyme lactate dehydrogenase showed significant differences between the two studied groups exhibiting significantly higher values in group $B$ than group $A$. The vitamin $C$ supplement seems to improve fish growth performance and influence important blood parameters that indicate the health status of fish (Percin \& Konyalioglu, 2008; Percin \& Sogut, 2010). This result will be helpful for food management in aquaculture systems of striped bass. Further investigations are necessary to better understand all the benefits brought about by the use of dietary vitamin $\mathrm{C}$ supplementation in different species of cultured fish.

\section{References}

Ai, Q., Mai, K., Zhang, C., Xu, W., Duan, Q., Tan, B., \& Liufu, Z. (2004). Effects of dietary vitamin $C$ on growth and immune response of Japanese seabass, Lateolabrax japonicus. Aquaculture, 242(1-4), 489-500.

Alexis, M. N., Karanikolas, K. K., \& Richards, R. H. (1997). Pathological findings owing to the lack of ascorbic acid in cultured gilthead bream (Sparus aurata L.). Aquaculture, 151(1-4), 209-218.

Azad, I. S., Dayal, J. S., Poornima, M., \& Ali, S. A. (2007). Supra dietary levels of vitamins $C$ and $E$ enhance antibody production and immune memory in juvenile milkfish, Chanos chanos (Forsskal) to formalin-killed Vibrio vulnificus. Fish \& Shellfish Immunology, 23(1), 154-163.

Chatterjee, I. B. (1973). Evolution and the biosynthesis of ascorbic acid. Science, 182(4118), 1271-1272.

Chen, R., Lochmann, R., Goodwin, A., Praveen, K., Dabrowski, K., \& Lee, K.-J. (2004). Effects of dietary vitamins $C$ and $E$ on alternative complement activity, hematology, tissue composition, vitamin concentrations and response to heat stress in juvenile golden shiner (Notemigonus crysoleucas). Aquaculture, 242(1-4), 553-569.
Dabrowski, K. (2000). Ascorbic acid in aquatic organisms: status and perspectives. CRC press.

Dadar, M., Adel, M., Ferrante, M., Nasrollahzadeh Saravi, H., Copat, C., \& Oliveri Conti, G. (2016). Potential risk assessment of trace metals accumulation in food, water and edible tissue of rainbow trout (Oncorhynchus mykiss) farmed in Haraz River, northern Iran. Toxin Reviews, 35(3-4), 141-146.

Darias, M. J., Mazurais, D., Koumoundouros, G., Cahu, C. L., \& Zambonino-Infante, J. L. (2011). Overview of vitamin D and $C$ requirements in fish and their influence on the skeletal system. Aquaculture, 315(1-2), 49-60.

De Andrade, J. I. A., Ono, E. A., De Menezes, G. C., Brasil, E. M., Roubach, R., Urbinati, E. C., ... Affonso, E. G. (2007). Influence of diets supplemented with vitamins $\mathrm{C}$ and $\mathrm{E}$ on pirarucu (Arapaima gigas) blood parameters. Comparative Biochemistry and Physiology Part A: Molecular \& Integrative Physiology, 146(4), 576-580.

Falahatkar, B. (2005). The effect of dietary vitamin C on some of hematologhc biochemistry and growth indexes of great sturgeon (Huso huso). Ph. D. Thesis, Tarbiat Modaarres University, Tehran, Iran (Persian).

Falahatkar, Bahram, Dabrowski, K., \& Arslan, M. (2011). Ascorbic acid turnover in rainbow trout, Oncorhynchus mykiss: Is there a vitamin enrichment effect during embryonic period on the juvenile fish "sensitivity" to deficiency? Aquaculture, 320(1-2), 99-105.

Fazio, F. (2019). Fish hematology analysis as an important tool of aquaculture: a review. Aquaculture, 500, 237-242.

Fazio, F, Faggio, C., Marafioti, S., Torre, A., Sanfilippo, M., \& Piccione, G. (2013). Effect of water quality on hematological and biochemical parameters of Gobius niger caught in Faro lake (Sicily). Iranian Journal of Fisheries Sciences, 12(1), 219-231.

Fazio, F, Saoca, C., Casella, S., Fortino, G., \& Piccione, G. (2015). Relationship between blood parameters and biometric indices of Sparus aurata and Dicentrarcus labrax cultured in onshore tanks. Marine and Freshwater Behaviour and Physiology, 48(4), 289-296.

Fazio, F, Saoca, C., Ferrantelli, V., Cammilleri, G., Capillo, G., \& Piccione, G. (2019). Relationship between arsenic accumulation in tissues and hematological parameters in mullet caught in Faro Lake: a preliminary study. Environmental Science and Pollution Research, 1-7.

Fazio, F, Saoca, C., Vazzana, I., \& Pic-cione, G. (2017). Influence of body size on Blood hemogram in rainbow trout Oncorhynchus mykiss (Walbaum, 1792). Vet Med Open J. 2, 91-94.

Fazio, Francesco, Arfuso, F., Levanti, M., Saoca, C., \& Piccione, G. (2017). High stocking density and water salinity levels influence haematological and serum protein profiles in mullet Mugil cephalus, Linnaeus, 1758. Cahiers De Biologie Marine, 58(3), 331-339.

Fazio, Francesco, Filiciotto, F., Marafioti, S., Di Stefano, V., Assenza, A., Placenti, F., ... Mazzola, S. (2012). Automatic analysis to assess haematological parameters in farmed gilthead sea bream (Sparus aurata Linnaeus, 1758). Marine and Freshwater Behaviour and Physiology, 45(1), 63-73.

Fazio, Francesco, Marafioti, S., Torre, A., Sanfilippo, M., Panzera, M., \& Faggio, C. (2013). Haematological and serum protein profiles of Mugil cephalus: effect of two different habitats. Ichthyological Research, 60(1), 36-42.

Gaglio, G., Reina, V., Caffara, M., Gjurcevic, E., laria, C., \& Marino, F. (2016). Risk of introduction of Clinostomum 
complanatum (Digenea: Clinostomidae) to Sicily through use of Cobitis bilineata (Canestrini, 1865) as live baits. Bulletin of the European Association of Fish Pathologists, 36(3).

Iaria, C, Ieni, A., Corti, I., Puleio, R., Brachelente, C., Mazzullo, G., \& Lanteri, G. (2018). Immunohistochemical study of four fish tumors. Journal of Aquatic Animal Health.

Iaria, Carmelo, Migliore, S., Macri, D., Bivona, M., Capparucci, F., Gaglio, G., \& Marino, F. (2019). Evidence of Centrocestus formosanus (Nishigori, 1924) in Zebrafish (Danio rerio). Zebrafish.

Iaria, Carmelo, Saoca, C., Guerrera, M. C., Ciulli, S., Brundo, M. V., Piccione, G., \& Lanteri, G. (2019). Occurrence of diseases in fish used for experimental research. Laboratory Animals.

Kiron, V., Puangkaew, J., Ishizaka, K., Satoh, S., \& Watanabe, T. (2004). Antioxidant status and nonspecific immune responses in rainbow trout (Oncorhynchus mykiss) fed two levels of vitamin $E$ along with three lipid sources. Aquaculture, 234(1-4), 361-379.

Kopp, R., Mareš, J., Lang, Š., Brabec, T., \& Ziková, A. (2014). Assessment of ranges plasma indices in rainbow trout (Oncorhynchus mykiss) reared under conditions of intensive aquaculture. Acta Universitatis Agriculturae et Silviculturae Mendelianae Brunensis, 59(6), 181-188.

Lewis-McCrea, L. M., \& Lall, S. P. (2010). Effects of phosphorus and vitamin $C$ deficiency, vitamin A toxicity, and lipid peroxidation on skeletal abnormalities in Atlantic halibut (Hippoglossus hippoglossus). Journal of Applied Ichthyology, 26(2), 334-343.

Lim, C., Klesius, P. H., Li, M. H., \& Robinson, E. H. (2000). Interaction between dietary levels of iron and vitamin $C$ on growth, hematology, immune response and resistance of channel catfish (Ictalurus punctatus) to Edwardsiella ictaluri challenge. Aquaculture, 185(3-4), 313-327.

Lin, M.-F., \& Shiau, S.-Y. (2005). Dietary L-ascorbic acid affects growth, nonspecific immune responses and disease resistance in juvenile grouper, Epinephelus malabaricus. Aquaculture, 244(1-4), 215-221.

Lo Cascio, P., Calabrò, C., Bertuccio, C., laria, C., Marino, F., \& Denaro, M. G. (2018). Immunohistochemical characterization of PepT1 and Ghrelin in gastrointestinal tract of zebrafish: effects of Spirulina vegetarian diet on the neuroendocrine system cells after alimentary stress. Frontiers in Physiology, 9, 614.

Marino, F., Di Caro, G., Gugliandolo, C., Spanò, A., Faggio, C., Genovese, G., ... Santulli, A. (2016). Preliminary study on the in vitro and in vivo effects of Asparagopsis taxiformis bioactive phycoderivates on teleosts. Frontiers in Physiology, https://doi.org/10.3389/fphys.2016.00459

Montero, D., Tort, L., Robaina, L., Vergara, J. M., \& Izquierdo, M. S. (2001). Low vitamin E in diet reduces stress resistance of gilthead seabream (Sparus aurata) juveniles. Fish \& Shellfish Immunology, 11(6), 473-490.

Nsonga, A. R., Kang'Ombe, J., Mfitilodze, W., Soko, C. K., \& Mtethiwa, A. H. (2009). Effect of varying levels of dietary vitamin C (ascorbic acid) on growth, survival and hematology of juvenile tilapia, Oreochromis karongae (Trewavas 1941) reared in aquaria. Brazilian Journal of Aquatic Science and Technology, 13(2), 17-23.

Okhionkpamwonyi, O. N., \& Edema, C. U. (2017). Effects of supplemental vitamin C (Ascorbic Acid) on the growth and health of African catfish Clarias gariepinus. Journal of Applied Sciences and Environmental Management, 21(1), 177-183.

Ortuño, J., Esteban, M. A., \& Meseguer, J. (2003). The effect of dietary intake of vitamins $C$ and $E$ on the stress response of gilthead seabream (Sparus aurata L.). Fish \& Shellfish Immunology, 14(2), 145-156.

Percin, F., \& Konyalioglu, S. (2008). Serum biochemical profiles of captive and wild northern bluefin tuna (Thunnus thynnus L. 1758) in the Eastern Mediterranean. Aquaculture Research, 39(9), 945-953.

Percin, F., Konyalioglu, S., Firat, K., \& Saka, S. (2010). Serum electrolytes of wild and captive Bluefin Tuna (Thunnus thynnus L.) in Turkish seas. Journal of Animal and Veterinary Advances, 9(16), 2207-2213.

Percin, F., \& Sogut, O. (2010). Magnesium levels in vital organs of bluefin tuna, Thunnus thynnus L., from the Turkish region of Eastern Mediterranean. Journal of Animal and Veterinary Advances, 9(21), 2768-2773.

Petric, M., Martins, M., Onaka, E., Moraes, J., Moraes, F., \& Malheiros, E. (2018). Suplementação alimentar com vitamina C potencializa a formação de macrófagos policariontes em Piaractus mesopotamicus Holmberg, 1887 (Osteichthyes: Characidae). Boletim Do Instituto de Pesca, 29(1), 69-76.

Puangkaew, J., Kiron, V., Somamoto, T., Okamoto, N., Satoh, S., Takeuchi, T., \& Watanabe, T. (2004). Nonspecific immune response of rainbow trout (Oncorhynchus mykiss Walbaum) in relation to different status of vitamin E and highly unsaturated fatty acids. Fish \& Shellfish Immunology, 16(1), 25-39.

Renò, F., Aina, V., Gatti, S., \& Cannas, M. (2005). Effect of vitamin $E$ addition to poly (D, L)-lactic acid on surface properties and osteoblast behaviour. Biomaterials, 26(28), 5594-5599.

Sahoo, P. K., \& Mukherjee, S. C. (2002). Influence of high dietary $\alpha$-tocopherol intakes on specific immune response, nonspecific resistance factors and disease resistance of healthy and aflatoxin B1-induced immunocompromised Indian major carp, Labeo rohita (Hamilton). Aquaculture Nutrition, 8(3), 159-167.

Sahoo, P. K., \& Mukherjee, S. C. (2003). Immunomodulation by dietary vitamin $\mathrm{C}$ in healthy and aflatoxin B1-induced immunocompromised rohu (Labeo rohita). Comparative Immunology, Microbiology and Infectious Diseases, 26(1), 65-76.

Sargent, J., Henderson, R. J., \& Tocher, D. R. (1989). The lipidsIn: Fish Nutrition (Ed.) JE Halver. Academic Press, San Diego.

Sau, S. K., Paul, B. N., Mohanta, K. N., \& Mohanty, S. N. (2004). Dietary vitamin $E$ requirement, fish performance and carcass composition of rohu (Labeo rohita) fry. Aquaculture, 240(1-4), 359-368.

Sealey, W. M., \& Gatlin III, D. M. (2002). Dietary vitamin C and vitamin $E$ interact to influence growth and tissue composition of juvenile hybrid striped bass (Morone chrysops? $\times$ M. saxatiliso') but have limited effects on immune responses. The Journal of Nutrition, 132(4), 748-755.

Shiau, S.-Y., \& Hsu, C.-Y. (2002). Vitamin E sparing effect by dietary vitamin $\mathrm{C}$ in juvenile hybrid tilapia, Oreochromis niloticus $\times$ O. aureus. Aquaculture, 210(1-4), 335-342.

Sogut, O., \& Percin, F. (2011). Trace elements in the kidney tissue of Bluefin Tuna (Thunnus thynnus L. 1758) in Turkish seas. African Journal of Biotechnology, 10(7), 1252-1259. 
Wilson, R. P., Halver, J. E., \& Hardy, R. W. (2002). Fish nutrition. Amino Acids and Proteins, pp. 143-179. San Diego, CA: Academic Press, Inc.

Zhou, Q., Wang, L., Wang, H., Xie, F., \& Wang, T. (2012). Effect of dietary vitamin $C$ on the growth performance and innate immunity of juvenile cobia (Rachycentron canadum). Fish \& Shellfish Immunology, 32(6), 969-975. 